\title{
Efek Ekstrak Teh Hijau terhadap Kadar Malondialdehid Nitrit Oksida dan Glutation Peroksidase Darah Tikus Putih Terpapar Plumbum
}

\author{
Effect of Green Tea Extract on Mallondialdehide, Nitric oxide and Gluthation Peroxidase \\ Activity on Blood Rats Exposured with Plumbum
}

\author{
Hernayanti $^{1 *}$, Ahmad Hamim Sadewa ${ }^{2}$, dan Bambang Hariono ${ }^{3}$ \\ 1Fakultas Biologi Universitas Jenderal Soedirman Purwokerto \\ 2 Fakultas Kedokteran Universitas Gadjah Mada Yogyakarta \\ 3Fakultas Kedokteran Hewan Universitas Gadjah Mada Yogyakarta \\ E-mail:hernayantioentoro@ymail.com*Penulis untuk korespondensi
}

\begin{abstract}
Lead is toxic to human. Green tea has been used to treat many kind of disease because of catechin. The objective of the studies were to know effect of catechin in green tea extract as a chelating agent of $\mathrm{Pb}$. Thirty six male Wistar rat were used in this studies. Rats were devided into 6 groups of 6 . First group as a negative control. The rest was the treatment groups that was given $\mathrm{Pb}$ acetate for 66 days. The second group as positive control. At the $35^{\text {th }}$ day of studies group III, IV, and V were given green tea extract at $0 \mathrm{~g} / \mathrm{kg}$ bodyweight, $0.75 \mathrm{~g} / \mathrm{kg}$ bodyweight, $1.5 \mathrm{~g} / \mathrm{kgbodyweight,} 3 \mathrm{~g} / \mathrm{kg}$ bodyweight respectively. The group VI was given dimercaprol as a standard clinical medicine. Parameter recorded were mallondialdehide, gluthation peroxidase activity and nitric oxide that measured by commercial kits. The different among treatments were analyzed using ANOVA, followed by Duncan to locate different. The result showed that all dosis of green tea extract could decrease MDA, blood lead and could increase serum GPx and NO. The optimum dosis was at $3 \mathrm{~g} / \mathrm{kg}$ bodyweigt that could decrease MDA for $2.75 \mu \mathrm{mol} / \mathrm{L}$ to $0.07 \mu \mathrm{mol} / \mathrm{L}$ and blood lead for $2.35 \mathrm{ppm}$ to $0.02 \mathrm{ppm}$ and increased serum GPx for $58.5 \mu$ $\mathrm{mol} / \mathrm{L}$ to $177 \mu \mathrm{mol} / \mathrm{l}$, serum NO for $1,2 \mu \mathrm{mol} / \mathrm{L}$ to $7.95 \mu \mathrm{mol} / \mathrm{L}$. It could be concluded that green tea extract could be used as a Pb chelator.
\end{abstract}

Keywords: Lead, catechin, glutathione peroxidase, nitric oxide

\begin{abstract}
Abstrak
Plumbum bersifat toksik terhadap manusia. Teh hijau digunakan untuk mengobati penyakit karena mengandung catechin. Tujuan penelitian untuk mengetahui efek catechin ekstrak teh hijau sebagai kelator Pb. Sebanyak 36 ekor tikus Wistar digunakan dalam penelitian ini. Tikus dibagi 6 kelompok, 6 ekor per kelompok. Kelompok I sebagai kontrol negatif. Kelompok II sampai VI diberi Pb asetat selama penelitian (66hari). Kelompok II sebagai kontrol positif tidak diberi perlakuan. Kelompok III, IV, dan V pada hari ke 35 diberi ekstrak teh hijau masingmasing 0,75 g/kgbb, 1,5 g/kgbb dan 3 g/kgbb. Kelompok VI diberi dimerkaprol dosis 3 g/kgbb sebagai pembanding. Ada tidaknya beda nyata antar perlakuan dianalisis dengan ANOVA diikuti dengan uji Duncan untuk mengetahui letak perbedaan. Parameter yang diukur adalah malondialdehid, aktivitas glutation peroksidase dan nitrit oksida, diukur dengan komersial kit. Hasil penelitian menunjukkan semua dosis ekstrak teh hijau dapat menurunkan MDA, Pb darah dan meningkatkan GPx serum serta NO. Dosis $3 \mathrm{~g} / \mathrm{kgbb}$ optimum dalam menurunkan kadar MDA dari 2,75-0,07 $\mu \mathrm{mol} / \mathrm{L}$ dan Pb darah dari 2,35-0,02 ppm. GPx serum meningkat dari 58,5-177 $\mu \mathrm{mol} / \mathrm{L}$ dan NO serum dari 1,2-7,95 $\mu \mathrm{mol} / \mathrm{L}$. Simpulan hasil penelitian, ekstrak teh hijau dapat digunakan sebagai kelator $\mathbf{P b}$.
\end{abstract}

Kata kunci: Plumbum, catechin, glutation peroksidase, nitrit oksida 